\title{
OS SENTIDOS DOS SILÊNCIOS NA EDUCAÇÃO: REPRESENTAÇÕES SOCIAIS DE PROFESSORES FORMADORES DA UNIVERSIDADE FEDERAL DE UBERLÂNDIA - MG
}

\author{
THE SENSES OF THE SILENCES IN THE EDUCACION: \\ TEACHER TRAINERS SOCIAL REPRESENTATIONS IN \\ UNIVERSIDADE FEDERAL DE UBERLÂNDIA - MG.
}

\author{
LOS SENTIDOS DEL SILENCIO EN EDUCACIÓN: \\ REPRESENTACIONES SOCIAL DE PROFESSORES ENTRENADORES DE LA \\ UNIVERSIDAD FEDERAL DE UBERLÂNDIA - MG.
}

\section{Vanessa Therezinha Bueno Campos ${ }^{1}$ Fernanda Duarte Araújo Silva ${ }^{2}$ Graça Aparecida Cicillini ${ }^{3}$}

\begin{abstract}
RESUMO: As reflexões sobre os silêncios na educação apresentadas neste artigo foram organizadas a partir de uma pesquisa realizada na Universidade Federal de Uberlândia (UFU), como um dos sentidos e significados das representações sociais, de docentes que atuam em cursos de licenciatura, sobre Educação para a Justiça Social. Apoiamo-nos na abordagem teórico-metodológica da Teoria das Representações Sociais (TRS) e na técnica de livre associação de palavras (ABRIC, 2001) para definir os procedimentos da pesquisa e elaborar os instrumentos de coleta de dados. Aplicamos um questionário com o uso da técnica de livre associação de palavras, instigadas a partir de um conjunto de 13 imagens com cem professores universitários. As palavras mais escolhidas, a partir desse conjunto de imagens, representam a abrangência de inserção do trabalho docente em diferentes contextos: espaços temporais, sociais, econômicos e culturais. Para este artigo, selecionamos discutir as representações de docentes relacionadas a uma das 13 imagens, denominada "Retratos silenciosos" (CÂMARA, 1975). As representações dos professores, relativas a essa imagem, referem-se às condições de aprendizagem e permanência na escola para o enfrentamento da exclusão social e cultural, destacando a necessidade de uma educação política com vistas ao exercício da Educação em Direitos Humanos. Em linhas gerais, percebemos que essa imagem despertou nos sujeitos sentimentos contraditórios movidos pela compreensão das violências, da indignação ou da aversão à situação e à tentativa de libertação dessas formas de representação.
\end{abstract}

PALAVRAS-CHAVE: Representação Social. Educação. Silêncio. Justiça Social. Formação de Professores.

\begin{abstract}
Reflections on the silences in education presented in this article were arranged from a survey conducted at the Universidade Federal de Uberlândia - UFU, as one of the senses and meanings of social representations of teachers working in undergraduate courses on Education Social Justice. We rely on the theoretical and methodological approach of the Social Representation Theory (SRT) and the technique of free association of words (ABRIC, 2001) to define the research procedures elaborate the data collection instruments. We applied a questionnaire using the free word association technique, instigated from a set of 13 images with 100 university professors. The most chosen words from that set of images represent the inclusion of coverage of

\footnotetext{
1 Doutora em Educação pela Universidade de São Paulo. Professora titular na Universidade Federal de Uberlândia, MG - Brasil. E-mail: vbcampos@ netsite.com.br.

2 Mestrado em Educação pela Universidade Federal de Uberlândia. Professora assistente da Universidade Federal de Uberlândia, MG - Brasil. E-mail: fernandaduarte.facip@ gmail.com.

3 Doutorado em Metodologia de Ensino pela Universidade Estadual de Campinas. Professora titular da Universidade Federal de Uberlândia, MG - Brasil. E-mail: gacicillini@gmail.com.
}

Recebido em: 5/6/2015 - Aprovado em: 29/7/2015.
\end{abstract}


teaching in different contexts: timelines, social, economic and cultural. For this article we selected discuss the representations of teachers related to one of the 13 images, called "Retratos silenciosos" (CÂMARA, 1975). The representations of the teachers regarding this refer to the conditions of learning and staying in school to face the social and cultural exclusion, highlighting the need for political education with a view to the exercise of Human Rights Education. Generally speaking, we realize that this image aroused mixed feelings in the subjects moved the understanding of violence, outrage or disgust the situation and attempt to release these forms of representation.

KEYWORDS: Social Representation. Education. Silence. Social Justice. Teacher Education.

RESUMEN: Las reflexiones sobre los silencios en la educación presentados en este artículo se organizaron a partir de una encuesta realizada en la Universidad Federal de Uberlândia - UFU, como uno de los sentidos y significados de las representaciones sociales de los docentes que trabajan en los cursos de licenciatura en Educación Justicia Social. Nos basamos en el enfoque teórico y metodológico de Teoría de las Representaciones Sociales (TRS) y la técnica de asociación libre de palabras (ABRIC, 2001) para definir los procedimientos de investigación y preparar los instrumentos de recolección de datos. Se aplicó un cuestionario utilizando la técnica de asociación libre de palabras, instigados por un conjunto de 13 imágenes con 100 profesores universitarios. Las palabras más elegidas a partir de ese conjunto de imágenes representan la inclusión de la cobertura de la enseñanza en diferentes contextos: plazos, sociales, económicos y culturales. Para este artículo hemos seleccionado discutir las representaciones de los profesores relativas a una de las 13 imágenes, llamado "Retratos silenciosos" (CÂMARA, 1975). Las representaciones de los profesores con respecto a este se refiere a las condiciones de aprendizaje y que permanezcan en la escuela para hacer frente a la exclusión social y cultural, destacando la necesidad de una formación política con miras al ejercicio de la Educación en Derechos Humanos. En términos generales, nos damos cuenta que esta imagen despertó sentimientos encontrados en los sujetos trasladaron la comprensión de la violencia, ultraje o asco la situación y tratar de liberar estas formas de representación.

PALABRAS CLAVE: Representación Social. Educación. Silencio. Justicia Social. Formación de Profesores.

\section{INTRODUÇÃO}

As mudanças ocorridas na educação brasileira, como resposta às exigências do processo de globalização mundial, ao avanço tecnológico e aos impactos da luta dos movimentos sociais por democratizar o acesso à Educação Básica e ao Ensino Superior, trazem consigo a necessidade de novos questionamentos a respeito da formação, do papel e das funções dos professores. Questões relativas ao reconhecimento dos direitos civis, à justiça social, à igualdade, à diversidade e à inclusão são colocadas na agenda social e política, na mídia, na esfera jurídica e na política educacional. Embora tais questões estivessem presentes no desenvolvimento da educação brasileira, nem sempre elas foram reconhecidas pelo poder público como merecedoras de políticas compreendidas como direito, ao qual se devem respostas públicas e democráticas, no sentido de que a educação passa a ser direito de todos, dever do Estado e da família, como preconiza o Art. 205 da Constituição Federal (BRASIL, 1988), com destaque para o desenvolvimento integral da pessoa, para a cidadania, promoção da igualdade e qualificação para o trabalho.

A escola, a partir dessa configuração, redimensiona-se continuamente e estabelece diálogos e conflitos em uma sociedade marcada pelas desigualdades e injustiças. Essa "nova" escola se reafirma sobre diferentes realidades socioeconômicas e culturais para atender aos direitos básicos de acesso e inclusão do cidadão brasileiro. Para tanto algumas modificações na estrutura do sistema ocorreram: a ampliação do número de escolas, do número de 
professores do tempo de escolaridade dos alunos, além do sistema de ciclos de formação e também o aumento da duração em dias de ano letivo. A massificação, como primeiras consequências dessas mudanças, traz outros problemas e coloca em "cheque" o princípio de justiça, com apelo à equidade. As políticas de inclusão não previram um dado significativo evidenciado pelos índices de reprovação e evasão escolar: o despreparo ou uma formação inadequada dos professores que não corresponde às necessidades e aos anseios sociais, principalmente das escolas públicas.

Nesse sentido, consideramos necessário relacionar esta reflexão à luta pela equidade e pela justiça social ${ }^{4}$, focando nos aspectos políticos do ensino e na construção do saber e do fazer diário na escola para questionarmos: Os professores formadores podem vincular suas reflexões, seus saberes e fazeres à luta pela equidade e pela justiça social no processo de formação de seus alunos?

Os professores como sujeitos sociais, assevera Zeichner (2003), têm capacidade de refletir, construir conceitos e dar qualificações culturais às coisas do mundo. Consequentemente, as representações docentes sobre educação e justiça social devem ser analisadas de acordo com seu modo de produção. As relações estabelecidas na escola, na sociedade influenciam nas reflexões, conhecimentos, intenções e intervenções dos docentes. Nessa perspectiva, consideramos necessário vincular essa reflexão à luta pela equidade e pela justiça social, especialmente focada nos aspectos políticos do ensino, bem como na construção do saber/fazer escolar. As proposições do autor nos instigam a pensar sobre a possibilidade de novas diretrizes de formação de professores para a justiça social que contribuam para:

\begin{abstract}
a diminuição das desigualdades existentes entre as crianças das classes baixa, média e alta nos sistemas de escola pública de todo o mundo e das injustiças que existem nas sociedades, fora dos sistemas de ensino: em relação ao acesso à moradia, alimentação, saúde, transporte, ao trabalho digno que pague um salário justo e assim por diante. A incerteza que caracteriza o contexto atual está relacionada ao futuro duvidoso que o planeta tem pela frente se as injustiças persistirem e nós continuarmos a ver grandes distâncias na educação e na renda entre ricos e pobres em toda a sociedade. (ZEICHNER, 2003, p.11)
\end{abstract}

A partir dessas considerações, neste artigo discutimos e analisamos as aproximações e os distanciamentos sobre educação para a justiça social com relação às representações de docentes formadores de professores de cursos de licenciatura relativas às diferentes formas de silenciamentos nas práticas formativas. As reflexões sobre "os sentidos dos silêncios na educação" foram organizadas a partir de uma pesquisa realizada por professores e estudantes da Universidade Federal de Uberlândia (UFU), com o intuito de apreender as representações

\footnotetext{
${ }^{4}$ Aqui compreendida em termos de reconhecimento e respeito dos direitos fundamentais da pessoa humana, à qual devem ser atendidos e assegurados de forma a preservar a vida. (DALLARI, 2010).
} 
dos professores formadores dos cursos de licenciatura da UFU sobre educação para a justiça social $^{5}$.

A partir da análise das representações docentes sobre os sentidos dos silêncios nas práticas formativas, articulada com os elementos teóricos - as discussões e análises das representações sociais de docentes sobre Educação, Justiça Social e Silenciamento foram respaldadas nas proposições de Arendt (2009), Giroux e Mclaren (1995), Freire (1980; 1987; 1994; 1996; 2000a; 2000b; 2001), Freire (2006), Zeichner (2003), Orlandi (2007); em relação às representações sociais utilizamos as elaborações de Moscovici (1978; 2007) e Abric (2001) -, podemos afirmar que os saberes docentes sobre educação para a justiça social é composto de diferentes dimensões, imbricadas e indivisíveis. Entendemos que tais saberes são mediados pelos saberes da experiência, concebida de forma ampla, envolvendo não só a experiência docente, mas de cidadão.

Esperamos que as reflexões sobre os sentidos dos silêncios nas práticas formativas suscitadas nesse texto contribuam ampliar as discussões e proposições de políticas para a formação docente, tais como: incluir, como eixos estruturantes dessa formação, os saberes pedagógicos e o diálogo permanente com as redes de ensino, a reflexão sobre as representações de educação para a justiça social no processo de formação docente; incorporar nas políticas de formação a atuação com a diversidade de alunos matriculados nas escolas. Mudanças dessa natureza podem auxiliar o processo formativo dos futuros professores no sentido da articulação de saberes complexos relacionados ao trabalho docente, do desenvolvimento profissional e do fortalecimento da opção por se constituir professor.

\section{CONHECENDO A PESQUISA}

Entendemos que a abordagem qualitativa nos possibilita imergir nas esferas da subjetividade e do simbolismo, fundamentados no contexto social, com peculiaridades de crença, valores, representações e significados específicos a cada indivíduo ou grupo (BOGDAN; BIKLEN, 1994, p. 49). Assim, esta investigação foi desenvolvida com a colaboração de docentes de cursos de licenciatura da Universidade Federal de Uberlândia, nos campi de Uberlândia e Ituiutaba, em Minas Gerais, no período de 2011 a 2014, em duas fases.

\footnotetext{
${ }^{5}$ A pesquisa "Formação docente para a diversidade: representações de professores formadores sobre educação e justiça social". Foi aprovada pelo Comitê de Ética (Parecer No 300511- Protocolo: 07250113.3.0000.5152) e financiada por CNPq. A investigação foi articulada às atividades de ensino e de extensão, sobretudo nos projetos de formação continuada de professores da Educação Básica, dos quais participamos de forma ativa por meio da oferta de Curso de Pós-graduação Lato Sensu em Educação em Direitos Humanos, promovido pela Faculdade de Educação da Universidade Federal de Uberlândia (2013 a 2014). A pesquisa foi realizada pelos dos integrantes do Grupo de Pesquisa "Formação docente e representações" em parceria com o Centro Internacional de Estudos em Representações Sociais e Subjetividades (CIERS - ED), criado pela Fundação Carlos Chagas (FCC), com o apoio do Laboratório Europeu de Psicologia Social (LEPS) da Maison des Sciences de I'Homme de Paris (MSH).
} 
$\mathrm{Na}$ primeira fase estabelecemos uma amostra representativa de professores de cada curso e aplicamos dois instrumentos: questionário e entrevista. Com o objetivo de aprofundar a análise das representações investigadas, na segunda fase foi organizado um grupo focal, tendo em vista o debate sobre educação para a justiça social na formação e prática docentes ${ }^{6}$.

Os instrumentos foram elaborados a partir das referências teórico-metodológicas da Teoria das Representações Sociais (TRS) e com base na técnica de livre associação de palavras (ABRIC, 2001), que tem como características a espontaneidade, a dimensão projetiva, a maior aproximação aos elementos que constituem o universo semântico do termo ou do objeto estudado e a emergência de elementos latentes que seriam ocultados ou mascarados nas produções discursivas. Todavia, no processo de construção do questionário e da entrevista, consideramos que os professores poderiam apresentar alguma dificuldade para expressarem verbalmente suas opiniões a respeito de educação para a justiça social. Optamos, então, por agregar à técnica de livre associação de palavras, imagens, com vistas a auxiliá-los na comunicação dos significados sobre o objeto investigado.

A seleção das imagens foi definida por professores e alunos que compõem o Grupo de Pesquisa e Estudos (CNPq) "Formação Docente e representações" da UFU. Cada integrante apresentou um conjunto de imagens que expressava a sua representação de justiça e injustiça social na instituição escolar, e para além dela, que se aproximavam dos conceitos estudados no referencial teórico sobre Educação para a Justiça Social. Esse processo, de acordo com a Teoria das Representações Sociais, é denominado "objetivação", que pretende tornar concreto o que é abstrato, transformando o conhecimento racional em imagem ${ }^{7}$.

Definimos um conjunto de 13 imagens que julgamos refletir as possíveis representações da temática em estudo. Esse conjunto foi dividido em dois grupos: (1) representações de educação para a justiça social na sociedade contemporânea; e (2) representações de educação para a justiça social no contexto escolar.

Na técnica de aplicação do questionário, o participante deveria: a) observar o conjunto de imagens e, para cada uma, escrever as quatro primeiras palavras que lhe vinham à cabeça; b) escolher quatro imagens que o auxiliassem a discutir o seu conceito de justiça social; e c) proceder da mesma forma com o segundo grupo de imagens, relacionando Educação para a Justiça Social ao contexto escolar e à formação de professores. Esse instrumento foi aplicado para cem professores de cursos de licenciatura.

\footnotetext{
${ }^{6} \mathrm{Na}$ cidade de Uberlândia, a UFU oferta 14 cursos de licenciatura, sendo que quatro deles oferecem a modalidade de licenciatura desvinculada do bacharelado, e os demais disponibilizam as modalidades bacharelado e licenciatura. Em Ituiutaba, onde há sete cursos de licenciatura, apenas a Pedagogia oferece somente licenciatura.

${ }^{7}$ As principais fontes de imagens foi o acervo do grupo de pesquisa e a internet, sendo que a autoria de cada uma delas foi contemplada e devidamente referendada conforme as normas da Associação Brasileira de Normas e Técnicas (ABNT) em vigência.
} 
Para a análise das palavras e expressões evocadas na questão de associação livre fizemos, inicialmente, a correspondência de sinônimos entre elas. Em seguida utilizamos o software EVOC com o intuito de identificar quais delas são as mais relevantes na constituição da representação social ${ }^{8}$.

A segunda fase foi organizada tendo em vista o debate sobre educação e o aprofundamento da análise das representações manifestadas na primeira fase da investigação. Para tanto, o grupo focal foi constituído por nove professores formadores que responderam o questionário e foram entrevistados na fase inicial. A ênfase de análise, por meio dessa técnica,

recai sobre a interação que se estabelece dentro do grupo e não em perguntas e respostas entre moderador e membros do grupo. A interação que se estabelece e as trocas efetivadas serão estudadas pelo pesquisador em função de seus objetivos. Há interesse não somente no que as pessoas pensam e expressam, mas também em como elas pensam e porque pensam o que pensam (GATTI, 2005, p. 9).

Nesses termos, a dinâmica do grupo focal foi organizada em três momentos. No primeiro, a coordenadora da pesquisa informou ao grupo aspectos relativos à temática, aos objetivos, às etapas da pesquisa e aos modos de tratamento dos dados; no segundo, promoveu a discussão entre os integrantes do grupo usando as quatro imagens mais selecionadas pelos sujeitos de pesquisa - para cada uma delas os professores, no grupo focal, deveriam escolher uma palavra, entre as mais citadas para tal imagem (oriundas da primeira etapa da pesquisa com os cem professores), que na opinião deles contribuíssem para a reflexão sobre Educação e Justiça Social; e no terceiro momento, foi proposto que os docentes, sujeitos da pesquisa, fizessem considerações sobre a relação educação para a justiça social na prática docente, enfatizando sua relevância e como desenvolvê-la.

Para analisar as questões abertas, referentes às justificativas da escolha da imagem que auxiliaria os docentes a discutirem e refletirem sobre educação para a justiça social na formação de professores, bem como o conhecimento sobre justiça social contemplado na formação docente, na primeira fase da pesquisa e nos depoimentos obtidos no grupo focal, optamos por utilizar a análise de conteúdo fundamentada em Bardin (2010), Minayo (1989) e Franco (2007).

A complexidade da investigação das representações sociais requer um cuidado criterioso, principalmente por sustentarem as práticas sociais diante do objeto representado. Definidas as temáticas diante de determinado assunto, podemos chegar ao núcleo de sentidos e significância. Nesse sentido, deve-se ficar claro que o importante não são as "palavras" em si ou o rastreamento de significados por meio de outros indícios, mas sim a síntese que esses

\footnotetext{
${ }^{8}$ Desenvolvido por Pierre Vergés (2002). É software prestante à análise de vocábulos. Sua tela de abertura apresenta o conjunto de programas a que ele submete as palavras para realizar as análises fatorial e de tipificação ou de agrupamento; possibilita a partir de 16 programas a análise das evocações léxicas e a categorização que é baseada no conceito de análise de conteúdo, de Bardin (1979), e faz análise quantitativa dos dados obtidos, agregando-os pela frequência e centralidade das evocações.
} 
indícios permitem elaborar a respeito das representações sociais sobre educação e justiça social.

Nessa perspectiva, destacamos que o trabalho com grupo focal revelou uma multiplicidade de pontos de vista e processos emocionais, pelo próprio contexto de interação criado, e permitiu a captação de significados que, com outros meios, poderiam ser difíceis de ser manifestados (GATTI, 2005, p. 9). Ao utilizarmos essa técnica, observamos as negociações e os consensos, por parte dos sujeitos, sobre as referidas representações, processos próprios da elaboração de representações sociais, articularam-se à análise dos dados com o propósito de identificar as representações investigadas, bem como compreender os processos de negociação de significados, verificando as forças que contribuem para a manutenção dessas representações e aquelas que sugerem possibilidades de mudança.

\section{OS SENTIDOS DOS SILÊNCIOS}

Segundo o depoimento dos professores, as imagens usadas para evocar as representações sociais relativas à temática "Educação para a Justiça Social na formação e prática docente" refletem a realidade e são muito provocativas. Reconheceram haver uma essência muito comum entre elas, que reflete a desigualdade social, o acúmulo de riqueza, a preservação e a educação. Um deles assim expressou: "Quando você vê essas imagens, reconhece alguma coisa, e é algo gritante" ${ }^{9}$.

Moscovici (1978) considera que as imagens são elementos significativos da representação social, pois também são construtoras da criação de significações e tornam possível a expressão simbólica do real, refletida a partir das ideias, dos signos e dos símbolos, capaz de transformar um objeto em imagem.

A imagem é um elemento significativo da representação social. Assim como ela, a representação "fala tanto quanto mostra, comunica tanto quanto exprime" (MOSCOVICI, 1978, p. 26). Essa concepção nos respaldou na apreensão das imagens sobre justiça e/ou injustiça social como um conjunto de fenômenos multifacetados, organizados em relações interdependentes, envolvendo vários sujeitos e suas relações com o espaço onde atuam, bem como os símbolos com os quais convivem. Nessa perspectiva, para a constituição da imagem coletiva sobre justiça ou injustiça social e formação de professores foi necessário o levantamento dos diversos pontos associados à objetivação e à ancoragem, capazes de revelar um quadro amplo de referência (informações, ideologias, normas, crenças, valores, atitudes, opiniões etc.).

\footnotetext{
${ }^{9}$ Optamos por inserir neste artigo extratos dos registros compilados nas entrevistas e no grupo focal. Para resguardar e garantir o sigilo identitário dos professores que participaram nas diversas etapas da pesquisa, organizamos um código numérico seguido pelo nome do curso de licenciatura ao qual estão vinculados.
} 
As imagens são espécies de sensações mentais, de impressões que os objetos e as pessoas deixam em nosso cérebro. Ao mesmo tempo, elas mantêm vivos os traços do passado, ocupam os espaços de nossa memória para protegê-los contra a confusão oriunda das mudanças e reforçam o sentimento de continuidade do meio ambiente e das experiências individuais e coletivas. As imagens não são neutras, e sim produtos de um determinado contexto, dado que foram construídas para determinados usos, sejam eles individuais ou coletivos. Vale ressaltar que uma imagem é capaz de forjar opiniões, reforçar ideias e até mesmo fomentar preconceitos em relação a um tema; é o olhar que organiza a experiência e produz sentido à imagem. O poder da imagem-coisa estabelece sentimentos e emoções, e é por meio delas que penetramos no inconsciente. As imagens que vão sendo construídas em cada ser humano dependem de como ele vê o mundo, ou seja, da sua forma de sentir, assimilar, abstrair e interpretar o que vê, dos sentidos que cria, estabelece e partilha. Os detalhes, mesmo se considerados subjetivos ou idiossincráticos, são ativados quando se olham imagens de família, de um acontecimento social, de um espaço geográfico modificado com o passar dos anos, do espaço escolar e de outras situações que são registradas de diferentes formas ao longo da história.

Do conjunto das 13 imagens analisadas pelos docentes, a Figura 1, apresentada a seguir, foi uma das que obteve maior destaque.

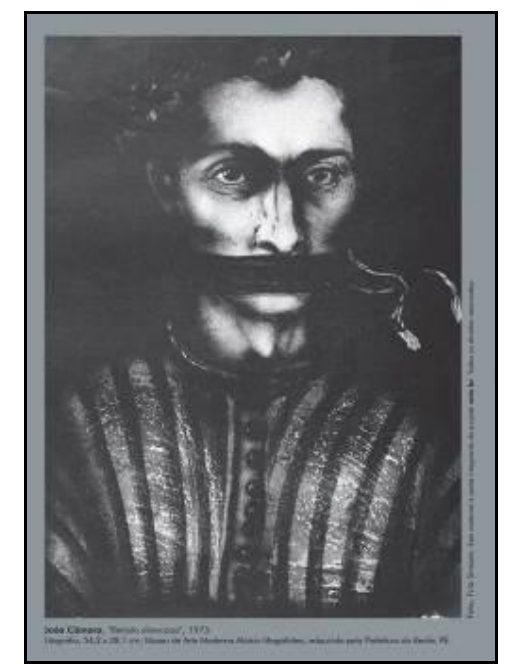

FIGURA 1 - Retratos Silenciosos (1975)

Fonte: João Câmara.

De acordo com as declarações dos professores, essa imagem é expressiva: as nuances em preto e branco revelam um homem com uma mordaça na boca; tem na face uma expressão tensa e aparenta olhar para algo que não é mostrado, convidando-nos a refletir a respeito do silêncio. Agregadas a essa palavra, outras expressões - guardar silêncio, impor silêncio, silêncio eloquente, minuto de silêncio, quebrar o silêncio, lei do silêncio, silenciar alguém, silêncio pungente etc. - nos fazem perceber que há uma gama de possibilidade de sentidos e de empregos do silêncio; isso confirma que ele é algo significante na vida e no discurso. 
Nas vozes dos docentes, a leitura da Figura 1 revelou o silêncio de palavras não ditas: censura, silêncio, liberdade, violência, sofrimento e opressão. Quando foi apresentada aos professores que participaram do grupo focal, tal imagem gerou discussões importantes para pensarmos a respeito de suas representações sobre Educação para a Justiça Social na formação e prática docente. Um dos sujeitos que escolheu a palavra "opressão" assim se justificou: "Eu escolhi a palavra opressão, porque parece que ele está querendo falar e não consegue. Ele quer falar, mas não pode. Está oprimido" (DOCENTE N. 11.378/QUÍMICA).

O silêncio pode representar uma sinalização, uma informação sob a forma de um olhar, ou uma postura, uma imobilidade, pois essas são mensagens enviadas ao outro. Orlandi (2007) afirma que o silêncio pode ser entendido em três perspectivas: a primeira diz respeito ao silêncio "imposto", ou seja, colocado como uma forma de dominação em que o sujeito é excluído, ficando sem voz, sem sentido, oprimido. A compreensão do silêncio imposto pode ser identificada na declaração de uma professora durante a entrevista:

Pensar em justiça social é pensar em sujeitos que pensam. Ao ver o homem silenciado nos processos educativos, isso contribui para o silenciamento, os medos de pensar a organização escolar (DOCENTE N. 04104/FACULDADE DE EDUCAÇÃO).

A segunda perspectiva, apresentada por Orlandi (2007), refere-se ao silêncio "proposto", que se apresenta como uma forma de resistência, defesa e proteção. Um dos professores declarou

\footnotetext{
Essa imagem [Figura 1] é importante na formação de professores para você ressaltar que todos têm direito de livre expressão, e não praticar na sala uma opressão contra os alunos e para que eles sejam cidadãos que tenham essa habilidade de livre expressarem-se. Creio que os estudantes silenciam, em geral, por meio de represálias, principalmente nas avaliações. (DOCENTE N. 04493/FACULDADE DE EDUCAÇÃO).
}

A autora também analisa o silêncio a partir de uma falha na comunicação, na emissão do que se tem a intenção de comunicar e que é por ela denominada como ruptura.

É impressionante a força dessa imagem [Figura1]; ela mostra como o homem está impedido de falar, contudo, apesar da mordaça, ele grita! (DOCENTE N. 04457/FACULDADE DE EDUCAÇÃO).

Esses diferentes modos de apreender o silêncio remetem aos sentidos dessa expressão presentes nos "não ditos" e em seus processos de constituição. Segundo Ferreira (1999), a palavra "silêncio", do latim silentiu, indica o estado de quem cala, a privação de falar, o sigilo, segredo. Cumpre salientar que o silenciamento não consta entre os verbetes apresentados pelo autor, mas se destaca que o barulho é o seu oposto: ruído, rumor, tumulto, desordem, alvoroço, motim, revolta.

Se o barulho é o oposto do silêncio, podemos depreender, a partir de relatos recorrentes de professores que atuam, desde a Educação Básica até o Ensino Superior, 
relativos à indisciplina na sala de aula, que a palavra se refere à insubordinação da norma, da ordem estabelecida. Nas declarações dos docentes foi possível também identificar a utilização da vigilância para manter a disciplina com a devida advertência sobre as consequências e os riscos que a prática de atitudes desaconselhadas pelo professor pode acarretar:

É preciso considerar também que o silêncio é importante, pois é difícil dar aula com conversinhas paralelas, além do uso do celular, entrar e sair, dormir e comer na sala. Tem uma coisa que eu não abro mão: quando eu falo, exijo silêncio (DOCENTE N. 011095/ENFERMAGEM).

Não podemos deixar de ressaltar que as reivindicações docentes desse tipo sejam pertinentes; não obstante, a educação escolar, ao longo da história - por vezes, em suas posturas e análises -, adotou critérios estigmatizadores nos moldes de seleção e avaliação no processo educativo. Tal postura nada mais é do que a busca da homogeneidade e traduz a incapacidade de se trabalhar com a diversidade.

A compreensão de uma educação pautada na homogeneidade revela uma concepção fundamentada no ideário funcionalista, ou seja, a concepção de que a sociedade é um sistema de elementos funcionalmente articulados: o indivíduo visto como produto social, e a educação, como processo de socialização. Nesse entremeio, a sociedade espera e exige que a instituição escolar e os professores sejam capazes de controlar o comportamento discente, porque entende que tais atores são responsáveis por aprimorar a formação do indivíduo em sua relação com o outro.

No discurso escolar e docente identificamos que o princípio constitucional de "Educação para Todos" foi assimilado, mas, por meio de suas práticas e conteúdos dominantemente estabelecidos, os docentes não compreendem ou não valorizam a diversidade de estudantes que possuem desigual capital de origem familiar e social, em que há expectativas e interesses díspares, e estabelecem conteúdos e conhecimentos, ritos pedagógicos homogeneizados, estáticos e lineares do ensino e da aprendizagem. Ainda prevalece no senso comum pedagógico, que compete aos professores, independentemente do nível de ensino, não apenas transmitir o conhecimento, o conteúdo, mas também estar atentos ao comportamento de cada estudante, além de orientar, incentivar e ajudá-los a manter e promover o bem-estar entre todos. Tal crença fundamenta-se na ideia de que os discentes serão capazes de aprender melhor, na medida em que se calam, subordinam-se ao mestre, seguem preceitos e normas, ajudam a acatar a disciplina escolar, as regras de comportamento em sala de aula (calar e falar ao comando do mestre), as indicações pedagógicas do docente (fazer tudo ao modo dele). Uma docente, ao optar pela palavra "censura", aproxima-se dessa forma de agir do seguinte modo: 
Há um dispositivo da censura na sociedade atual, modificado sutilmente. Estamos o tempo todo censurados [avaliados]. Boa oportunidade para pensar qual dispositivo utilizamos sobre os sujeitos [estudantes] na sala de aula. O que nós estamos entendendo por justiça social? Dispositivos seculares de disciplinarização estão entre nós (DOCENTE N. 04104/FACULDADE DE EDUCAÇÃO).

Em geral, o silenciamento revela-se como componente controlador da (in)disciplina e é percebido no aspecto de dominação, opressão, imposição do professor sobre o aluno, principalmente no tocante à avaliação, ainda entendida como controle, punição ou prêmio. A disciplinarização como controle também pode ser entendida como silenciamento, censura e violência, palavras que também foram evocadas nas discussões realizadas entre os professores durante o grupo focal: "Escolho a palavra "violência". Achei que a pessoa aqui [Figura 1] está violentada e possui o olhar sofrido. A imagem remete ao sofrimento. Os olhos dele clamam por liberdade" (DOCENTE N. 12434/CIÊNCIAS BIOLÓGICAS).

A desigualdade de classes, o preconceito, o desrespeito e a discriminação em qualquer relação ou espaço social são formas de violência. Percebemos que a análise da imagem selecionada desencadeou sentimentos contraditórios entre os entrevistados, movidos pela compreensão das violências, indignação ou aversão a uma situação de opressão, assim como pela tentativa de libertação desta.

Freire (2000a, p. 136) se posiciona a favor da liberdade, da justiça, da ética e da autonomia do ser humano, da escola, da sociedade, mas considera que "estamos ainda no processo de aprender como fazer democracia". Este sentimento também se fez presente nas discussões ocorridas no grupo focal:

Essa [Figura 1] me chamou a atenção pela possibilidade da democracia, direitos de opinião. Incomoda-me a questão da censura, sobretudo hoje em dia, que é uma censura velada. Então, não existe a possibilidade de ter um pensamento livre nem mesmo na universidade (DOCENTE N. 05158/SOCIOLOGIA).

As reflexões do docente são pertinentes, entretanto, aos discentes ainda é reservado um espaço mais silencioso e até mesmo silenciado do que aos docentes. Enquanto estes ainda são chamados para expressarem suas opiniões, àqueles só resta se calar e aceitar. A esse respeito, nas discussões realizadas no Grupo Focal dois professores assim se posicionaram

Devemos romper com esse silêncio que nos cerca. $\mathrm{O}$ aluno precisa ter o direito de falar, de se posicionar, dizer o que concorda e o que não concorda. Só assim teremos a oportunidade de melhorar nosso quadro educacional (DOCENTE N. 21667/HISTÓRIA).

Essa imagem [Figura 1] é importante na formação de professores para você ressaltar que todos têm direito de livre expressão, e não praticar na sala uma opressão contra os alunos e para que eles sejam cidadãos que tenham essa habilidade de livre expressarem-se (DOCENTE N. 04493/FACULDADE DE EDUCAÇÃO).

Consideram Giroux e Mclaren (1995, p.137) que é necessário entender a voz do estudante, pois segundo os autores: 
A voz do estudante é um desejo, nascido da biografia pessoal e da história sedimentada; é a necessidade de construir-se e afirmar-se em uma linguagem capaz de reconstruir a vida privada e conferir-lhe significado, assim como de legitimar e confirmar a própria existência no mundo. Logo, calar a voz de um aluno é destituílo de poder.

A violência acontece no espaço político, justamente quando os indivíduos são "silenciados", impedidos de dizer a sua palavra, de se afirmar como sujeitos no plano da ação. Compreender a violência como ausência da palavra, que silencia os sujeitos retirando sua dimensão de participação política e de empoderamento, torna-se essencial para o estudo da violência na perspectiva dialógica-conflitiva. A referência ao sujeito oprimido e silenciado se evidencia, tal qual afirma Freire (1996), não apenas no indivíduo que está subjugado economicamente, mas em especial naqueles que estão às margens culturais, cujos valores, linguagens, religiões, opções diversas não são respeitados. São esses sujeitos que, oprimidos, são silenciados.

De acordo com Arendt (2009) os termos poder e violência, muitas vezes são confundidos e tratados como sinônimos. A autora, não apenas diferencia poder e política de violência, mas coloca-os em espaços contraditórios: "poder e violência são opostos; onde um domina absolutamente, o outro está ausente". A violência aparece, enfatiza a autora, onde o poder está em risco, mas, “deixada a seu próprio curso, ela conduz à desaparição do poder” e, nessa perspectiva, é justamente a ausência de poder, que corresponde "à habilidade humana não apenas para agir, mas para agir em concerto" (ARENDT, 2009, p. 60 e 73).

A violência, afirma Spósito (1998, p. 60), é todo "ato que implica na ruptura de um nexo social pelo uso da força. Nega-se, assim, a possibilidade da relação social que se instala pela comunicação, pelo uso da palavra, pelo diálogo e pelo conflito".

Nesse sentido, a ação coercitiva e opressora presentes nas relações que se estabelecem na sala de aula, na escola e para além dela, de limitar a livre manifestação da opinião, impedindo a manifestação da palavra, do diálogo, é uma forma de violência. Freire (1987, p. 31) apresenta outros questionamentos e nos convida a refletir: "Quem, melhor que os oprimidos, se encontrará preparado para entender o significado terrível de uma sociedade opressora? Quem sentirá, melhor que eles, os efeitos da opressão? Quem, mais que eles, para ir compreendendo a necessidade da libertação?”.

No Brasil, uma parcela significativa de estudantes matriculados nas escolas públicas encontra-se em situação de fracasso escolar, algo que ocorre num contexto de vigência de legislação educacional nacional e de acordos internacionais, que preconizam o direito à escolarização, independentemente de classe social, gênero, raça/etnia, deficiência, entre outras condições do sujeito ${ }^{10}$. Tal processo de exclusão se apresenta, muitas vezes, camuflado

10 A esse respeito, cabe mencionar a Declaração Mundial sobre Educação para Todos: satisfação das necessidades básicas de aprendizagem (UNESCO, 1998), a Declaração de Salamanca (UNESCO, 1994) e a Lei de Diretrizes e Bases da Educação Nacional (BRASIL, 1996). 
por discursos institucionalizados, os quais contribuem para asseverar as relações de desprestígio. A esse respeito, um dos professores colaboradores assim se pronunciou:

Esse discurso que está fortalecido é um discurso de inclusão que atende a interesses econômicos do neoliberalismo. Incluir para que esse sujeito dê um retorno para sociedade enquanto um consumidor. Você pode ver pela própria legislação. Cria uma falsa ideia que "eu desejo que a justiça social seja atendida". Porque quando se discutem as ideias étnico-raciais, se discute de forma superficial, não se discute para provocar mudanças na sociedade, no máximo há transformações discursivas. A universidade não quer assumir nenhum compromisso com as questões das diferenças, porque ela diz que isso deveria ser feito na Educação Básica. Mas, quem é que forma os profissionais que atuam na Educação Básica? Como que uma pessoa formada no Ensino Superior vai ter compromisso com essas questões se ela não teve nenhum fundamento teórico aqui? [...] Nesse assunto de justiça social fíco pensando onde na universidade essa questão passa. Qual é o nosso compromisso social de fato? (DOCENTE N. 04116/FACULDADE DE EDUCAÇÃO).

As reflexões e questionamentos apresentados pelo docente demonstram que é necessário compreender a exclusão social como uma situação de privação coletiva de uma parcela significativa da população, a negação do exercício pleno da cidadania que deve ser construída a partir do acesso de todos aos direitos civis, políticos e sociais. Tal ideário corrobora com as proposições de Sposati (1996, p. 13 e 30):

[...] a exclusão social é a impossibilidade de poder partilhar da sociedade e leva à vivência da privação, da recusa, do abandono e da expulsão, inclusive com violência, de uma parcela significativa da população. Por isso exclusão social e não só pessoal. Não se trata de um processo individual, embora atinja pessoas, mas de uma lógica que está presente nas várias formas de relações econômicas, sociais culturais e políticas da sociedade. Esta situação de privação coletiva é que se está entendendo por exclusão social. Ela inclui pobreza, discriminação, subalternidade, não equidade, não acessibilidade, não representação pública. É, portanto, um processo múltiplo que se explica por várias situações de privação da autonomia, do desenvolvimento humano, da qualidade de vida, da equidade e da igualdade [...] a exploração econômica, social, é uma exclusão social. Todavia, o processo de exclusão social atual é mais do que marginalização e opressão. Hoje estão em pauta as discrepâncias e as disparidades das condições da vida humana entre países, cidades, bairros, classes, segmentos, etc. Esta disparidade leva ao convívio de situações infra-humanas - como o homem ou a criança de rua - com outras de alta concentração de qualidade de vida e desenvolvimento humano (SPOSATI, 1996, p.13 e 30)

A realidade brasileira é caracterizada pela multiplicidade de fatores que geram a desigual distribuição de renda e produz uma sociedade em que a pobreza provoca a desintegração familiar, principalmente em núcleos de baixa renda, nos quais predominam comportamentos de abandono e maus tratos. Essa situação, conforme Carvalho (1992),é reflexo da deterioração do nível socioeconômico das famílias, gerando uma multidão de excluídos, sendo as crianças e os adolescentes as pessoas mais desprotegidas da sociedade.

O discurso oficial e recorrente é o da "Educação para Todos". Não obstante, parecenos fundamental refletir sobre os limites desse discurso para fomentarmos o ensino para cada aluno matriculado atualmente nas escolas públicas do nosso país, na perspectiva de não delimitar o atendimento educacional restrito às denominadas aprendizagens básicas e, ainda, 
identificar e analisar os mecanismos que colaboram para preservar duas situações conflitantes concernentes à educação como um direito humano: "educação para todos" e "a produção da exclusão de muitos dos processos de escolarização". Como se pode pensar em valorizar todos, com as suas diferenças, se os diferentes são justamente os silenciados nesse processo?

Moscovici (2007) destaca a existência de uma padronização dos sujeitos e das coisas a partir das representações sociais. Segundo ele, as representações convencionalizam objetos, pessoas ou acontecimentos: os sujeitos que não se adéquam a essa realidade, por exemplo, não são compreendidos ou aceitos pela sociedade. É desse processo de "modelos sociais" que decorrem os discursos que marcam alguns indivíduos como superiores e outros como inferiores, seja pela idade, etnia, posição social ou recusa a aderir um padrão qualquer.

Vale ressaltar que o contexto no qual estão inseridos os estudantes difere no que tange a crenças, valores, comportamentos, origem social e posição econômica. Por esse motivo, o respeito às diferenças entre os indivíduos é fundamental, especialmente na interação social que se consolidará na educação. Contudo, o que ocorre é a negação das particularidades dos alunos ou o silêncio ao diferente, insistindo-se na uniformização dos indivíduos e da cultura escolar. O silenciamento nos conteúdos curriculares apresenta-se em relação aos indivíduos da terceira idade, do mundo rural e litorâneo, da classe trabalhadora e das pessoas com necessidades educativas especiais e diferenciadas orientações de gênero. Para Louro (2000), é a voz socialmente aprovada/autorizada que inclui e exclui sujeitos e conhecimentos, deliberando apenas as identidades ou os saberes que podem integrar o currículo.

A educação escolar no Brasil, seja na Educação Infantil, no Ensino Fundamental ou Médio, principalmente no sistema privado de ensino, é preocupada em atender aos critérios de seleção do aluno para ingressar na universidade ou no mercado de trabalho. Nessa perspectiva, reproduz e reforça estereótipos que limitam o trabalho pedagógico, pois somos educados para o "vir a ser", porque somente nos tornaremos adultos, de acordo com essa concepção. Nesta perspectiva, a importância do papel que o indivíduo desempenha na sociedade está indissociavelmente relacionada à posição que ocupará no mercado de trabalho. É nesse sentido que os pressupostos pedagógicos e curriculares, fundamentados na lógica do mercado definem os fins da avaliação como categoria que legitima os processos de seleção e as escolhas que privilegiam relações e criam campos de poder mediante a organização do conhecimento.

O processo educacional, tal como ele é instituído e se desenvolve, seleciona e coloca "para fora" muitos alunos não adaptados aos ditames de nossas instituições escolares. Se não fizermos essa reflexão, estaremos tão somente enredados no dia a dia, tentando resolver um problema aqui ou apagar um incêndio ali, mas tudo permanecerá exatamente como está, pois, combateríamos os sintomas e deixaríamos as causas intactas. Silva (1998, p. 10) considera que o campo educacional, assim como o âmbito social, não pode ser facilmente fechado, contido, fixado, reprimido, colonizado. Se for fechado, ele irrompe; se for contido, transborda; se for fixado, excede; se for reprimido, se rebela; se for colonizado, resiste, ou seja, transborda, rebela-se e resiste nas vozes muitas vezes silenciosas ou silenciadas dos excluídos. Identificar e escutar essas vozes não é tarefa simples, visto que, para muitos, ainda 
é mais confortável continuar na rotina, repetindo fórmulas ou fazendo mudanças superficiais que não alcançam o cerne da crise.

De fato, as mudanças são lentas e as instituições são refratárias a elas, mas o momento sócio-histórico nos exige a redefinição do que é, afinal, o fracasso ou o sucesso na educação escolar. Pouco ou nenhum resultado concreto advirá de reformas educacionais que adicionem novas camadas de tinta a uma estrutura cujos fundamentos têm sérias deficiências. Em vez de se repensar todo o sistema, acrescentam-se disciplinas ou temas, na tentativa de suprir as lacunas existentes. Nesse sentido, o currículo, conforme Silva (2011, p. 192-194), pode e deve ser revisado e questionado:

\begin{abstract}
Quais conhecimentos estão incluídos e quais conhecimentos estão excluídos do currículo? Quais grupos sociais estão incluídos - e de que forma estão incluídos - e quais grupos sociais estão excluídos? Como resultado dessas divisões, dessas inclusões e exclusões, que divisões sociais - de gênero, de raça, classe - são produzidas ou reforçadas? E, naturalmente, a pergunta mais importante a ser feita é: Qual nosso papel, como educadores e educadoras nesses processos de divisão e, portanto, de relações de poder? [...] é no currículo que o nexo entre representação e poder se realiza, se efetiva [...] as narrativas, as categorias, as culturas dos diferentes grupos sociais estão representadas no currículo de acordo com as relações de poder entre esses grupos sociais.
\end{abstract}

Observam Candau e Moreira (2003, p. 161) que não existe educação que não esteja imersa em processos culturais do contexto em que se situa. Nesse sentido, não é possível conceber uma experiência pedagógica "desculturizada", isto é, desvinculada das questões culturais da sociedade, pois o universo escolar é caracterizado pela:

[...] relação entre as culturas, relação essa atravessada por tensões e conflitos. Isso se acentua quando as culturas crítica, acadêmica, social e institucional, profundamente articuladas, tornam-se hegemônicas e tendem a ser absolutizadas em detrimento da cultura experiencial, que, por sua vez, possui profundas raízes socioculturais [...]. A escola sempre teve dificuldade em lidar com a pluralidade e a diferença. Tende a silenciá-las e neutralizá-las. Sente-se mais confortável com a homogeneização e a padronização [...] abrir espaços para a diversidade, a diferença, e para o cruzamento de culturas constitui o grande desafio que está chamada a enfrentar (CANDAU; MOREIRA, 2003, p. 161).

A escola é uma das instituições sociais, na qual se materializam relações entre distintos sujeitos e instâncias, carregados de experiências e tramas de suas culturas; é um espaço em que diferentes sujeitos se encontram e as diversas expressões culturais se manifestam, e na perspectiva da diversidade, o que se deve almejar não é a adaptação do indivíduo àquilo que a escola e a sociedade esperam dele, mas definir uma política de educação que considere a diversidade de comportamentos de forma a possibilitar uma convivência pacífica entre os indivíduos. Nesse sentido, a educação ética, a educação em direitos humanos e a educação para a diversidade e cidadania surgem como dimensões diferenciadas, porém entrelaçadas. Em todas elas são impostas reflexões sobre os fins e procedimentos da educação, seja na educação geral ou na especificidade da educação escolar e sobre a prática educativa, seus limites e a responsabilidade que the tem sido atribuída. Segundo Freire (1996, p. 42): 
Uma das tarefas mais importantes da prática educativo-crítica é propiciar as condições em que os educandos em suas relações uns com os outros e todos com o professor ensaiam a experiência profunda de assumir-se. Assumir-se como ser social e histórico como ser pensante, comunicante, transformador, criador, realizador de sonhos, capaz de ter raiva porque capaz de amar. Assumir-se como sujeito porque capaz de reconhecer-se como objeto. A assunção de nós mesmos não significa a exclusão dos outros.

Quando analisamos o processo em que se desenvolveram (e se desenvolvem) a democracia e a efetivação da cidadania, pensamos em uma escola que contribua para a formação de pessoas, orientadas para a participação social, com respaldo por valores como tolerância, equidade e justiça social. Para fazê-lo de forma coerente com a democracia, entendemos que a educação deve se pautar em princípios e ações que traduzam o ideal buscado, pois a concretização dos ideais democráticos depende da educação, como uma medida que visa à igualdade de oportunidades. Para tanto, Freire $(1994$, p. 154; 157) afirma ser necessário o reconhecimento da unidade na diversidade.

A unidade na diversidade tem de ser a eficaz resposta dos proibidos de ser, à velha regra dos poderosos: dividir para reinar. O caminho para assumir-se como maioria está em trabalhar as semelhanças entre si e não só as diferenças e assim, criar a unidade na diversidade, fora da qual não vejo como aperfeiçoar-se e até como construir-se uma democracia substantiva, radical [...] Uma criação histórica que implica decisão, vontade política, mobilização, organização de cada grupo cultural com vistas a fins comuns [...] demanda uma certa prática educativa coerente com esses objetivos e uma nova ética fundada no respeito às diferenças.

A prática pedagógica assentada em tais valores se vincula a uma ação educativa para a liberdade, em que o respeito para com o outro é essencial e imprescindível na dinâmica escolar e social. Isso significa reconhecer, nas diferenças existentes entre os diversos atores sociais, as alternativas para o enfrentamento e a superação dos descompassos e problemas sociais. Tal trabalho não ocorre isoladamente e requer modificações nas práticas didáticometodológicas como forma de estreitar o vínculo entre justiça social, cultura e educação. Diante disso destacamos a importância da formação inicial, nos cursos de licenciatura, explicitada no depoimento que se segue:

Na minha formação inicial eu tive uma formação muito forte na discussão do que é
justiça social, na própria ordem da organização social, e isso foi muito intenso. Mas,
muito pela vertente da distribuição, muito pela vertente do econômico. A questão
cultural ficou um pouco a desejar. E hoje eu vejo que eu trabalho isso de uma forma
muito mais intensa com meus alunos, porque eu discuto as temáticas e problematizo
todas as temáticas que estão ligadas à justiça social, que está associada ao modo como se
distribui renda, ao modo como se distribuem recursos, ao modo como se distribuem
oportunidades e ao modo como o outro pode ser considerado. Eu discuto, por exemplo,
a questão indígena, da diversidade cultural e a questão de sermos iguais também. E
quando a gente problematiza isso no estudo das temáticas, aí eu vejo que estou dando
um passo muito à frente daquela formação inicial que eu tive (DOCENTE N.
04113/GEOGRAFIA).

A formação docente exige estratégias que possibilitem a superação de qualquer forma de dominação e exploração do ser humano, substituindo práticas e ações permeadas por relações de exclusão e preconceitos por práticas educativas imbricadas por valores sociais 
comprometidos com o respeito às diferenças, à valorização da realidade local e, consequentemente, do educando que dela faz parte.

[...] pela educação podemos criar condições de entender a pobreza, a exclusão e construir um novo modelo de sociedade. A educação está tanto a serviço da manutenção da condição de marginalização, como a serviço da transformação. Eu procuro trabalhar a educação no sentido de transformar a realidade, no sentido de instrumentalizar as pessoas para que elas compreendam a realidade na qual elas estão vivendo e os motivos que levam essa realidade a se constituir do jeito que ela está se constituindo (DOCENTE N. 04116/CIÊNCIAS BIOLÓGICAS).

Quando nos referimos em ouvir as vozes silenciadas (sejam de alunos, de pais ou de professores), chamamos atenção para o fato de que, sendo a escola um espaço de convivência, de intersubjetividades, o exercício da alteridade não pode prescindir da liberdade de ideias, pensamentos e da própria construção do conhecimento, das contradições e conflitos que corporificam e atuam cotidianamente nesse espaço. A liberdade se conquista por meio da luta empreendida por "sujeitos históricos, e, pela solução dos conflitos, objetiva e prioritariamente, pelo diálogo amoroso" (FREIRE, 2006, p. 388).

\section{CONSIDERAÇÕES FINAIS}

As reflexões apresentadas nesse estudo foram constituídas a partir dos significados e dos sentidos das representações professores de cursos de licenciaturas sobre educação para a justiça social, na perspectiva de convivência, cidadania, ética e valores sociais. Nessa interlocução pudemos apreender os saberes docentes sobre sentidos dos silêncios na prática educativa oriundos de suas experiências pessoais e profissionais em diversos contextos, bem como identificar seus contornos, limites e conflitos.

A Figura 1 analisada neste texto aflorou, nos professores que participaram da pesquisa, percepções relacionadas à indignação ou aversão às diferentes formas de violência, bem como a tentativa de libertação desta. Entre os termos utilizados pelos docentes para atribuir significado à imagem estão: silêncio, silenciamento, censura e opressão.

O aspecto da representação do conhecimento docente sobre o objeto investigado e compartilhado foi o da prática da ética, na relação intersubjetiva com os outros. Nas declarações dos docentes identificamos que as suas práticas didático-pedagógicas, de maneira explícita ou implícita, se articulam com um ideário a respeito dos valores humanos integrados às ações, da necessidade de respeito ao outro, de compromisso na convivência social.

Consideramos relevante a discussão fomentada entre os professores sobre a diferença entre o direito à educação e a oportunidade de acesso à educação de qualidade por todos. A conotação dada pelos participantes é a de reivindicação de mais igualdade, concretizada pela mobilização de um sentimento de injustiça diante da avaliação da desigualdade de oportunidades. O processo de silenciamento foi percebido pelos participantes como limitador da efetivação dos direitos humanos, reforçando as posturas que dificultam a consciência do 
outro, a percepção do valor do bem coletivo, bem como a vivência de desigualdades de oportunidades.

De acordo com as declarações dos docentes a educação para prover a justiça social se realiza por meio do diálogo, do acesso ao conhecimento e, na prática, por meio de experiências relacionais, na instituição escolar, entre professor, aluno e instituição, bem como na relação desses sujeitos com o contexto social mais amplo em que os valores são transmitidos. $\mathrm{Na}$ diversidade dos contextos em que acontece a formação humana, a instituição universitária foi evocada pelos participantes como um espaço de relações significativas para essa formação, onde ocorre a vivência dessas contradições e conflitos, por compartilhar a ideologia social e por ter seus próprios valores na qualidade de instituição educacional.

Nesse sentido, a profissionalização docente constitui-se como um desafio, na perspectiva de possibilitar que as práticas de ensinar e aprender nas Instituições de Ensino Superior se reorganizem, sobretudo para dar conta de uma nova perspectiva epistemológica, em que as habilidades de intervenção no conhecimento sejam mais valorizadas do que a capacidade de armazená-lo. Tal preocupação tem como justificativa o próprio princípio norteador das ações de uma instituição de ensino superior, que não deve visar exclusivamente à formação profissional do professor, assegurando a aprendizagem de fundamentos e metodologias, mas também favorecer o processo geral de socialização de seus estudantes. Dessa forma, estará possibilitando a conscientização de seus acadêmicos sobre a vida que os cerca e, fundamentalmente, assumindo o compromisso de sua formação integral com qualidade e ética.

Consideramos que a presença da temática "educação para a justiça social na formação docente", inicial e continuada, demanda repensar a instituição educacional em seu conjunto, com vistas a promover trocas e gerar um processo de autocrítica e autoanálise. Não é um caminho fácil de ser percorrido. É um processo em construção. Sem dúvida, este caminho se constrói, em grande parte, por meio da decisão política de professores dispostos a assumirem a docência com compromisso e determinação, elaborando os saberes próprios de sua ação docente, como profissionais e seres humanos.

\section{REFERÊNCIAS}

ABRIC, Jean-Claude. A abordagem estrutural das representações sociais. In: MOREIRA, Antônia Silvia Paredes (Org.); OLIVEIRA, Denise Cristina de (Org.). Estudos

interdisciplinares de representação social. 2. ed. Goiânia: AB, 2001.

ARENDT, Hannah. Sobre a violência. Rio de Janeiro: Civilização Brasileira, 2009.

BARDIN, Laurence. Análise de conteúdo. Lisboa: Edições 70, 2010.

BOGDAN, Robert; BIKLEN, Sari. Características da investigação qualitativa. In: BOGDAN, Robert; BIKLEN, Sari. Investigação qualitativa em educação: uma introdução à teoria e aos métodos. Porto: Porto Editora, 1994. 
BRASIL. Constituição da República Federativa do Brasil. Brasília: Senado Federal, 1988. Disponível em: 〈http://www.mec.gov.br>. Acesso em: 1 jul. 2013.

BRASIL. Lei n. 9.394, de 20 de dezembro de 1996. Estabelece as Diretrizes e Bases da Educação Nacional. Diário Oficial da União, Brasília, 21 dez. 1996.

CÂMARA, João. Retratos silenciosos. 1975. Litografia, 54,2 x 38,1 cm. Museu de Arte Moderna Aloísio Magalhães, adquirido pela Prefeitura do Recife, PE. Foto: Fritz Simons.

CARVALHO, Antonio. Exclusão e violência: reflexões preliminares. In: Sociedade civil e educação. Campinas: Papirus Cedes; São Paulo: Ande-Anped, 1992.

CONFERÊNCIA MUNDIAL SOBRE EDUCAÇÃO PARA TODOS. Declaração mundial sobre educação para todos: Satisfação das Necessidades Básicas de Aprendizagem. Jomtien, 1990. UNESCO, 1998. Disponível em:< http://unesdoc.unesco.org>. Acesso em: 18 jan. 2011.

CONFERÊNCIA MUNDIAL SOBRE NECESSIDADES EDUCATIVAS ESPECIAIS. Declaração de Salamanca sobre princípios, política e práticas na área das necessidades educativas especiais, de 10 de junho de 1994. Disponível em:〈http://unesdoc.unesco.org〉. Acesso em: 25 nov. 2009.

DALARI, Dalmo. A. Direitos humanos e cidadania. São Paulo: Moderna, 2004.

FERREIRA, Aurélio Buarque de Holanda. Novo dicionário da língua portuguesa. Rio de Janeiro: Nova Fronteira, 1999.

FRANCO, Maria Laura Puglisi Barbosa. Análise do conteúdo. Brasília: Liber Livro, 2007.

FREIRE, Ana Maria Araújo. Educação para a paz segundo Paulo Freire. Educação, Porto Alegre, n. 2 (59), p. 387 - 393, mai./ago. 2006. Disponível em < http://goo.gl/ydwe7W>. ISSN: 1981-2582.

FREIRE, Paulo. Educação como prática da liberdade. 10. ed. Rio de Janeiro: Paz e Terra, 1980.

FREIRE, Paulo. Pedagogia da autonomia: saberes necessários à prática educativa. São Paulo: Paz e Terra, 1996.

FREIRE, Paulo. Pedagogia do oprimido. Rio de Janeiro, Paz e Terra, 1987.

FREIRE, Paulo. Pedagogia da esperança: um reencontro com a pedagogia do oprimido. 3. ed. Rio de Janeiro: Paz e Terra, 1994.

FREIRE, Paulo. A educação na cidade. 4. ed. São Paulo: Cortez, 2000a.

FREIRE, Paulo. Pedagogia da indignação: cartas pedagógicas e outros escritos. São Paulo: Editora da Unesp, 2000b.

FREIRE, Paulo. Política e educação. 5. ed. São Paulo: Cortez, 2001. 
GATTI, Bernadete Angelina. Grupo focal na pesquisa em ciências sociais e humanas. Brasília: Líber Livro, 2005.

GIROUX, Henry; MCLAREN, Peter. Formação do professor como uma contra-esfera pública: a pedagogia radical como uma forma de política cultural. In: MOREIRA, Antônio Flávio (Org.);

SILVA. Tomaz Tadeu (Org.). Currículo, cultura e sociedade. São Paulo: Cortez, 1995.

LOURO, Guacira Lopes. Currículo, gênero e sexualidade. Porto: Porto Editora, 2000.

MINAYO, Maria Cecília de Souza (Org.). Pesquisa social: teoria, método e criatividade. Petrópolis: Vozes, 1989.

MOREIRA, Antônio. Flávio Barbosa; CANDAU, Vera Maria. Educação escolar e cultura(s): construindo caminhos. Revista Brasileira de Educação: Rio de Janeiro: mai./jun./jul./ago., n. 23, 2003. p.156-168. Disponível em: < http://goo.gl/LfPdZ0>. Acesso em: 05 mai. 2015. ISSN: 1809449X.

MOSCOVICI, Serge. A representação social da psicanálise. Rio de Janeiro: Zahar, 1978.

MOSCOVICI, Serge. Representações sociais: investigações em psicologia social.

Petrópolis: Vozes, 2007.

ORLANDI, Eni Pulcinelli As formas do silêncio: no movimento dos sentidos. 6. ed.

Campinas: Ed. Unicamp, 2007.

SILVA, Tomaz Tadeu da. A escola cidadã no contexto da globalização: uma introdução. In: SILVA, Luiz Heron da (Org.). A escola cidadã no contexto da globalização. Petrópolis: Vozes, 1998.

SILVA, Tomaz Tadeu da. Currículo e identidade social: territórios contestados. In: SILVA, Tomaz Tadeu (Org.). Alienígenas na sala de aula: uma introdução aos estudos culturais em educação. 9. ed. Petrópolis: Vozes, 2011.

SPÓSITO, Marília Pontes. A instituição escolar e a violência. Caderno de Pesquisa, São Paulo, n.104, p. 58-75, 1998. Disponível em: < http://goo.gl/aAQxHz >. Acesso em: 05 jun. 2015. ISSN: $1980-5314$.

SPOSATI, Aldaíza de Oliveira. Mapa da exclusão/inclusão social na cidade de São Paulo. São Paulo: EDUC, 1996.

VÈRGES, Pierre. Conjunto de programas que permitem a análise de evocações: EVOC (manual). Versão 5. Aix en Provence: [S. n.] 2002.

ZEICHNER, Kenneth. Formando professores reflexivos para uma educação centrada no aluno: possibilidades e contradições. In: BARBOSA, Raquel Lazzari Leite (Org.) Formação de educadores: desafios e perspectivas. São Paulo: UNESP, 2003. 


\section{Como citar este documento:}

CAMPOS, Vanessa Bueno; SILVA, Fernanda Duarte Araújo; CICILLINI, Graça Aprecida. Os sentidos dos silêncios na educação: representações sociais de professores formadores da Universidade Federal de Uberlândia - MG.. ETD - Educação Temática Digital, Campinas, SP, v. 17, n. 2, p. 442 462, ago. 2015. ISSN 1676-2592. Disponível em:

<http://periodicos.sbu.unicamp.br/ojs/index.php/etd/article/view/8635725>. Acesso em: 28 ago. 2015. 